\title{
DROPPING LIKE FLIES: Another Death at Chowchilla California Women's Facility Joann Walker
}

On February 24th, 1994 at about 11:20 PM, Molly Reyes began to die here at Central California Women's Facility. Molly began to throw-up blood and some kind of inside body tissue in great amounts. The officer that was working in the building, unit 511 did all he could do to get help for Molly. He did his job and called medical staff. I have been informed that medical staff did not respond for one hour. The officer called five or six places trying all in his power to get Molly Reyes help as soon as he could.

The statement that it took the medical department one hour to respond was given by Molly's roommates. This is outrageous! The roommates were doing all they could do, they pulled globs of blood and tissue out of her mouth. When medical did respond the inmate (Molly Reyes) was taken to the make shift infirmary. The roommates were informed that Molly was dead at 3:00 A.M. on the 25th of February 1994, which the roommates don't believe, they feel she died in the room with them.

At 8:00 AM February 25th, 1994, one of Reyes' roommates that was very close to her called Molly's family to say how sorry she was. Hold on to your seats! The family had not been informed of their loved one's death!! This caused the inmate who called much pain. A pain so great that I can not begin to put it on paper.

On top of losing a good friend, and a good room mate the women in building 511 room one were dealt another blow. They had to clean up their dead peer's blood!! Molly Reyes was 50 years old, what a waste! What awful pain she must have been in, what kind of nightmares will her room mates have? How many more women will have to die for someone to wake-up to the medical horrors that are going on in the name of justice, here at Central California Women's Facility? Will the next one be a friend of yours, or your daughter, wife, mother, sister, grandmother, your lover? Only time will tell. 